\title{
MARTIN LUTHER KING JR'S PHILOSOPHY OF NON-VIOLENCE: A PARADIGM FOR GLOBAL BLACK RACE TOWARDS CONFLICT RESOLUTION AND PEACE IN AFRICA
}

\author{
Onoh John Ulafor \\ Department of Philosopy, University of Calabar, Cross River State, Nigeria. \\ E-mail: ulaforjohn@yahoo.com.
}

\begin{abstract}
The black race has suffered indignation across the globe through the machinations of oppressive, discriminatory and racist tendencies of developed nations. In United States and Europe, the black man in history had been consistently dehumanized and faced by social injustice. In this article I intend to articulate and examine the possible ways of how the black race could resolve conflicts and attain peace in Africa and across the globe. This would be done through the paradigm of non-violence philosophy of Martin Luther King Jr. Cognizance is accorded to the fact that, the non-violence paradigm had been successfully utilized by Martin Luther King Jr. in the United States to conquer racial discrimination and social injustice. I conclude in this paper that the reliance and efficacy of non-violence in conflict resolution and peace in Africa is a possibility.
\end{abstract}

Keywords: Non-violence, Black race, Conflict Resolution, Peace

\section{INTRODUCTION}

The black race has suffered enormous discrimination and oppression arising from social injustice committed against it. This scenario was prevalent in the United States of America during the days of Martin Luther King Jr. For him the best way to stop and eradiate this dominance, racial discrimination and segregation was through his advocacy and promotion of non-violence. Martin Luther King Jr. had frowned at the use of violence in conflict resolution because violence only begets violence, and if violence is allowed to continue, its vicious circle will continue with devastating consequences against humanity.

King Jr's conviction of the efficacy of non-violence was deeply rooted in his moral, spiritual Christian belief and more particularly the teachings of Jesus Christ's social philosophy (Eyo 2019: 27). Importantly, King Jr. was not born to meet non-violence, rather he learnt about non-violence resistance as espoused by Gandhi and other advocates of nonviolence. King Jr. was not convinced that non-violence could effectively work and be functional in disputes between large groups especially large society like United States where obvious racial segregation against black Negroes was practiced. But with the support of committed Christian Negroes who rally with King Jr. the evil of segregation and other social conflicts against the black Negroes were resolved. At this juncture, the recondite question is; what is the background to Martin Luther King's Philosophy of non-violence upon which the global black race could resolve conflicts and attain peace in Africa.

A. Background To Martin Luther King Jr's Philosophy Of Non-Violence Martin Luther King Jr. also known as MLK was born in Atlanta, Georgia, in the year 1929. He was brought up in a religious home, his father was a pastor. King Jr. followed in his father's footsteps and was ordained as a Minister of a Baptist Church in the city of Montgomery, Alabama. Within this period, there was a high rate of racial discrimination and segregation targeted at the Blacks in Montgomery, Alabama. The dominant character was that of the 
whites superiority over the Blacks people. The Blacks were treated as slaves and noncitizens. Richard Gregg (1960) reiterated that;

Through the Southern states of the United States, customs and state laws have combined to segregate Negroes from whites in respect to hotels, restaurants, schools, housing, use of parks and recreation grounds, waiting rooms in railways stations, on trains, buses, street cars and all sorts of public facilities. In many localities in such states, Negroes were not and are still not allowed to vote (36).

Gregg (1960) added that the problem started with the bus boycott:

In the buses, the first four rows of seats from the front, holding about ten persons, were reserved for the whites, and theoretically the last three rows of seats were reserved for Negroes. But if a white person boarded the bus when the front four rows were filled with whites and the last rows filled with Negroes, the bus driver would ask a Negro to "move back" and he would have to stand while the white person took his seat. Sometimes this request was made courteously, but often rudely and insultingly (36-37).

It was on one of these occasions and precisely on December $1^{\text {st }}, 1955$ that a Negro seamtress by name Rosa Park refused to obey such an order that she should vacate her seat for a white folk, which later warranted her being arrested and charged to court. This scenario sparked all the fights against all forms of segregation directed at the Blacks which was in form of protests organized by the blacks. Martin Luther King Jr was at the head of these protests and he ensured that their actions and activities were peaceful. Gregg speaks more on this matter thus: "They (the Blacks/Negroes) choose as President of the Negroes, Martin Luther King Jr... who had pondered social problems earnestly and been much influenced by Thoreau's essay on "Civil Disobedience" and the teaching and program of Mahatma Gandhi (1959: 38). However, the non-violence protest was carried out successfully through the biblical influences of Martin Luther King Jr. especially Jesus Christ social philosophy which was enshrined in the Sermon on the Mount. (Eyo, 2019: 20-27).

\section{B. King Jr's Philosophy Of Non-Violence, Conflict Resolution And Peace}

Violence in the society is often given birth to by conflict, challenges, crises and other social vices (Edet 2003; Edet 2014). To this end, Eyo and Ojong are of the view that: "Mankind throughout history evidence that our nature is characterized by conflict of thoughts, ideas, actions, interests, values, and dispositions. Little wonder that Heraclitus argued that everything is in the state of flux. In the face of this variations, conflict captures other synonyms like flux, opposites, misunderstanding, misconceptions, misapprehension, anarchy, disorderliness, confusion, unsystematicity, illogicality, violence and at the extreme war" (2008:1).

Furthermore, Eyo and Francis asserts "conflict resolution engenders peace in human society. Philosophers, scholars, peace advocates, sociologists and leaders have written momentous volumes of literature and developed differential methodologies on conflict resolution. On the one hand, philosophers such as Martin Heidegger, Mahatma Gandhi, Confucius, Martin Buber, Immanuel Kant, Martin Luther King Jr., Leo Tolstoy, David Thoreau and Chavez have developed philosophical frameworks and methodologies for 
nonviolent method of conflict resolution. On the other hand, philosophers like Frantz Fanon, Malolm X, Walter Rodney, Friedrich Nietzsche, Karl Marx, and Hegel have developed philosophical framework on violent methods of conflict resolution recently peace initiatives have been proposed and developed by Ephraim Essien (Debellihifism), Jim Unah (Phenomenology of Tolerance), Campbell Momoh (Conflictology), and Ungbo Ekweale (Ndu Mmili Ndu Azu) (Eyo and Francis 2017:138).

From the excerpts, Martin Luther King Jr. is a figure to be remembered for his nonviolence advocacy especially as it appertains to the racial discrimination in Montgomery. Luther saw this attack and resolved that something needed to be put in place to end this social injustice. As the President of Montgomery Improvement Association, he insisted that he will not rest until all the Black men, women and children are free from segregation; (discrimination and maltreatment). King Jr. showed great leadership by his demonstration of non-violent and protests.

As a man of intelligence, determination and integrity, he used his intelligence well when he refused to fight back violently against the white racists. If he had done that, many people would have been killed or seriously injured and the blame would have been placed on him as the head. By using his initiatives and moral conscious he was able to show that the use of violence would only give birth to another set of violence. King Jr. showed his determination by getting through jail, where he was severely punished, hit with sticks, fists and being called a "Niger". The good thing is that, he never allowed the punishment overcome him emotionally. He encouraged the black people not to be afraid in the whites community. King Jr. took responsibility for his actions by accepting a jail term. The climax of his commitment to non-violence became obvious when he accepted or allowed himself to be killed. This showed that he was ready before his death to give his life to have desegregation and to have his people gain freedom from the hands of the whites. Martin Luther King Jr. handed this creed to his followers;

In his words, through violence, you may murder the liar but you cannot murder the lie, not establish the truth... Darkness cannot drive out darkness; only light can do that. Hate cannot drive out hate, only love can do that. The beauty of non-violence is that in its own way and in it time. It seeks to break the chain reaction of evil king (1986: 62-63).

The point raised above is that a liar is not the major problem if one is in search for justice and equality but the lie is. To this end, Garrow (1986) said King Jr. indentified "three evils which are inherent in the need of injustice and inequality, which are "racism, economic exploitation and militarism (564). From these evils are various branches of unjust laws, oppression and subjection of the blacks. King Jr. called for a revolution in values to fight these interconnected evils. Garrow (1986) still reported thus: "We've to find a method that will disrupt our cities if necessary, create the crisis that will force the nation to look at the situation... and yet at the same time not destroy life or property" (580).

King Jr. in his acceptance speech for the Nobel peace prize said: "First, non-violence was not for cowards... it took great courage to place oneself unarmed and defenseless in front of a gang of white racists or heavily armed police officer... second, non-violent was not used to humiliate or defeat opponents, it is for friendship and converting the opponents... thirdly, non-violence should be used to fight the evil and not the person caught in these evil forces. Fourthly, non-violence was beneficial because it avoided the physical harm that 
violence inflicted on the body and finally that non-violence remedy tilt that forces of the universe toward justice. Based on these, the non violent activities will be equipped with knowledge to withstand pains and sufferings without retaliating... (Herman 1998: 129-130). This excerpt has a great touch on King Jr's non-violence Philosophy. Explaining further King Jr. said 'beloved community' could be achieved only through peaceful and harmonious integration of the whites and blacks, poor and rich, Jews and Gentiles. The 'beloved community' and true peace would not be achieved by simply eliminating evil forces of racism and segregation but it must include and embrace the positive forces of justice, goodwill and brotherhood.

However, King Jr. further opined, "Integration is the key element that will create the beloved community. Integration is creative, profound and positive (Nojeim 2013: 194). Integration unchains the spirit and recognizes the connection between all the people. At the centre of integrationist philosophy and the vision of his beloved community was powerfully expressed in the famous King Jr's. I have a dream speech, during the march on Washington soil in August 1963. This speech was a very powerful plea, not only for the fellowship of all humanity but for the down trodder blacks in the United States. A few thoughtful lines would sum up Kings Jr's oratory potency, full of alliteration, cadence rhythm and anaphora.

I have a dream that one day this nation will rise and live out the true meaning of the creed that all men are created equal. I have a dream that one day even the state of Mississippi will be transformed into the Oasis of freedom and justice. I have a dream today. I have a dream that one day right here in Alabama little black boys and little black girls will be able to join hands with little white boys and girls as sisters and brothers. I have a dream that my four little children will one day live in a nation where they will not be judged by the colour of their skin but by the content of their characters. (Carson, 1998: 2260).

I have a dream has future implication. It predicted the total liberation of the blacks from the rough hands of the white racists. It also established that fact that integration of the Negroes and the whites will one day in history (future) become a necessity. In short, I have a dream is a paradigm shift mechanism for the social liberation of the black race.

Furthermore, Martin Luther King Jr. placed pre-eminence on the word 'Agape' which mean love but not the romantic love. For him 'agape' is the realization and recognition that all people live and fully intertwined with one another as part of God's way and as part of a single process binding all of humanity. Oates puts it thus, "Agape was a way to forgiveness and restoration of the beloved community involving harmonious relationships with all God's children (1982: 33). King Jr. constantly advised his followers to exercise agape with everybody even those who oppress them. For him, 'agape' is the understanding, creative, redemptive goodwill toward all men, it enables us to love every man not because are like him or because his ways appeal to us but because God loves him (Ansbro 1982: 8). For Branch, "Agape is when you love those whose ways are distasteful to you. You love every man because God loves him (774). Oates still reported that in the court judgment in Montgomery, King Jr. insisted that non-violent resistance was not based on winning rights for blacks but achieving friendship with those denying those rights (1982: 290). King Jr's teaching is very impressive and human humane as well as godly and timely for peaceful coexistence. 
Speaking on justice and just war, King Jr. said justice was very critical for the growth and stability of any country, without justice King contends that there will be open doors for potential violence. For the sake of justice he asked. Why were the whites interested in maintaining order than achieving justice (Garrow 1986: 478). Consequently, the non-violent practitioners must have faith in the future, as he accepts suffering without retaliation, be should ensure alignment with the cosmic order of the universe (Eyo and Francis 2017: 143). This is an indication that linked justice and faith in non-violence.

\section{King Jr. 'S Principles Of Non-Violence}

Martin Luther King Jr.'s principles of non-violence runs in the following sequence:

1. Non-violence is a way of life for courageous people.

2. Non-violence seeks to win friendship and understanding: The end result of nonviolence is redemption and reconciliation. The purpose of non-violence is the creation of the beloved community.

3. Non-violence holds that evil doers are also victims. This means that non-violence seeks to defeat injustice, not people.

4. Non-violence holds that voluntary suffering can educate and transform. Nonviolence accepts suffering without retaliation. Suffering can have the power to convert the enemy when reason fails.

5. Non-violence chooses love instead of hate. Non-violence resists violence of the spirit as well as of the body. Non violent love gives willingly, knowing that the return might be hostility. Non-violence love is active, not passive. Non-violence recognizes the fact that all life is interrelated. Love restores community and resists injustice.

6. Non-violence believers that the universe is on the side of justice. The non-violent resister has deep faith that justice will eventually win. King Jr. said:

a. Learn all you about the problems you see in your community through the media, social and civic organizations, and by taking to the people involved.

b. Armed with your new knowledge, it is your duty to help those around you, such as your neighbours, relatives, friends and co-workers, better understand the problems facing society. Build a team of people devoted to finding solutions. Be sure to include those who will be directly affected by your work.

c. Accept that will face many obstacles and challenges as you and your team try to change society.

d. Agree to encourage and inspire one another along the journey.

e. Talk with both aides. Go to the people in your community who are in trouble and who are deeply hurt by society's ills. Also go to those people who are contributing to the breakdown of a peaceful society. Use humor, intelligence and grace to lead to solutions that benefit the greater good.

f. This step is often used when negotiation fails to produce results, or when people need to draw broader attention to a problem. It can include tactics such as peaceful demonstrations, letter writing and petition campaign.

g. Keep all actions and negotiations peaceful and constructive. Agree to disagree with some people and with some groups as you work to improve society. Show all involved the benefits of changing, not what they give up by changing. 
These and more are the steps according to Martin Luther King Jr. toward integration and reconciliation of the various conflict situations.

\section{King Jr's Philosophy Of Non-Violence, Global Black Race Towards Conflict} Resolution And Peace In Africa: The Discourse

This part of the paper examines the crux of the discourse, which is King Jr's Philosophy of non-violence in the perspective of global black race towards conflict resolution and peace in Africa. Cognizance is accorded the fact that Africa is the birth bed of global black race. Other black race flourished in United States and European nations.

Globally, the black race is faced with conflict situations, adversities, segregation and discrimination. This social injustice and inequality are against natural justice, good conscience and equity. This machination arises because of ethno-linguistic fragmentation of Africa by these oppressors. There are also high level of poverty, failed political states and economic dependence on foreign nations. Also these situations make peace elusive and resolutions of conflicts difficult. In the dictates of these foreign nations, perception of Africans and black race aspirations, in roots and inspirations are characterized by the phrase "nothing positive can come from Africa". These frames ignite the question, when would the global black race accomplish social and economic liberation? The answer to this question is found on the utilization of a peaceful and non-violent strategies.

The logic that flows from these predicaments of the global black race when placed within the paradigm of Martin Luther King Jr's Philosophy of non-violence suggest his key point of "Agape". According to Martin Luther King Jr. Agape which is the highest form of "love" galvanizes the faith and dependence on Christ's social philosophy which furnishes the spirit of love, justice, redemption and bearing the cross of suffering (Eyo 2019: 20-27) for the world.

The black people in Africa and elsewhere in Europe and United States of America need to adapt and adopt the spirit of King Jr's Agape in the face of adversities, conflicts and aspiration for peace. This reminds the oppressed black race that, we are operating from a very disadvantaged and weak positions and the only way to move ahead is by the show of love (Agape). King Jr's insistence in the show of love to the oppressors was hinged on his cognizance of the futility of violence. In this discourse, it is evident that his placement of value on non-violence made him a quite-essential patriot who believed and had faith in America. Apparently, King Jr believed that blacks in America could provide a guiding light for the rest of the world to follow" (Nojeim 2013: 272). The black race no matter their place of habitation ought to exhibit patriotism, ought to love Africa and think of transformation models of peace advancement in Africa. Non-violence model in conflict resolution in Africa is a mandatory vision for bringing justice to global black race.

Similarly, King Jr's principle of integration is another key point in his non-violence philosophy. According to his proposals on integration, King Jr articulated that integration with other races and people of the world will bring the needed inclusiveness in universal visions of humanity. This will bring up global oneness of all citizens of the universe. Again integration philosophy serves as a foundation for his "beloved community", a coinage which every human being ought to unify his destiny. The integration philosophy is another factor in conflict resolution, where King Jr argued that, it is application to all blacks and human beings across the nations of the world. King Jr. in his bid to enthrone non-violence as the 
only commitment he had articulated for all human beings believed that "injustice anywhere is a threat to justice everywhere (Nojeim 2013: 273). As stated hitherto, the major cause of segregation and discrimination against the black race is the over dependence on the ideals of the oppressors. The facts remain that, resources in Africa are unexploited except they are being facilitated and approved by foreign oppressive powers.

King Jr. had also averred that "non violent practitioners ought to be courageous, for a non violent resister does not need to be a coward". To support this C. Eric Lincoln held that "the peculiar genius of MLK is that he was able to translate religious fervor into social action thereby creating political leadership under the rubric of his religious ministry" (1984:xii, Nojeim 2013: 269, Eyo, 2019: 20-27). This depicts that his courage implore the black race to intensify non-violence in conflict resolution and social liberation.

Martin Luther King Jr's total disapproval of violence in conflict resolution is evident in this assertion "violence is always a descending spiral, leading nowhere. This is the ultimate weakness of violence. It multiples evil and violence in the universe. It does not solve any problem" (Cone 1993:270, Eyo and Essien 2017: 64-74). This averment is obvious in Africa, as violence cannot solve any problem rather it aggravate our dwindling state of poverty and social injustice. King Jr. justifies non violence in black people liberation in these words "if blacks resorted to violence, like black nationalists advocated, they would be annihilated by the more numerous better armed and better trained white opponents who would have no excuse but to unleash all their tools of violence with an awesome fury" (Washington 1984: 64, Eyo \& Etta 2020, 39-43).

This excerpt captures the picture of practical condemnation of the use of violence in resolution of terror, riots and even severe conflicts. Again the depiction of this excerpt is that non-violence works more effectively and efficiently for global black race to regain social justice and resolution of conflicts in Africa. Eyo and Etta (2020) points out the inefficacy and futility of violence in conflict resolution in Africa as Boko Haram activities are still active, the presence of AI-Queda in Sahel Region and North Africa and xenophobia in South Africa and other insecurity and challenges in Somaha, Sudan and South Sudan (39-43) betrays that violence cannot resolve conflicts and terror attacks in Africa.

The fundamental lesson extracted from the above excerpt is found in the sentiments of His Holiness the Dalai Lama which run thus "Retaliation that involves the use of further violence may not be the best solution in the long run... Terrorism cannot be overcome by the use of force because using force does not address the complex underlying problems. In fact the use of force may exacerbate them" (Government of Tibet in Exile 2002, Nojeim; 2013: 289-291).

In addition, “...violence undoubtedly breeds more violence if we instinctively retaliate when violence is done to us, what can we expect other than our opponents to all feel justified in retaliating. This is how violence escalates" (Government of Tibet in Exile 2002, Nojeim 290, Eyo and Essien 2017: 62-74).

\section{CONCLUSION}

In this article, I attempted to give an account of Martin Luther King Jr's non-violence philosophy as a paradigm for the global black race towards conflict resolution and peace in Africa. I reiterated the background to Martin Luther King Jr's philosophy of non-violence and the influences which encouraged King Jr. to be committed to non-violence especially in 
a large society like United States. The account of this non-violence was hinged on the racial discrimination against the blacks in United States. This commitment of King Jr's nonviolence further proposed the principles of integration and beloved community where unified humanity would approximate human interdependence and harmonious livelihood. Basic principles of King Jr's non-violence constitute and draw a framework for conflict resolution and peace in Africa.

Finally, the weakling frames and dependency of African nations to foreign powers do not require violence, since Africa's social defenses cannot confront and stand against the mercenaries of the white supremacist paradigm. The paper suggests that non-violence solves conflict inclined issues and create peace for the global black race and Africa by making notable contributions to humanity and comity of nations.

\section{REFERENCES}

Ansbro, J. J. (1982). Martin Luther King Jr. The Making of Mind, Maryknol N. V: Orbis Books.

Branch, Taylor, (1988). Parting the waters: America in the King Years; New York; Simon and Schuster.

Carson, C. E. (Ed) (1998). The Autobiography of Martin Luther King Jr. New York Warner Books.

Edet, M. (2003). A Case for the Abolition of Capital Punishment in Nigeria. Ndunode: Calabar Journal of Humanities, 137-150.

Edet, M. I. (2014). Human Values and Their Foundations: Towards an Ethic of Living Right (EOUSLY). Research on Humanities and Social Sciences, 4(2), 128-134.

Eyo, E. B. (2012). Frantz Fanon's Model of Conflict Resolution. Leajon: An Academic Journal of Interdisciplinary studies, 3(2).

Eyo, E. B. (2019). Jesus Christ the philosopher: An exposé. International Journal of Philosophy and Theology IJN 7(2), 20-27

Eyo, E. B., \& Essien, A. E. (2017). Frantz Fanon's Philosophy of Violence and the Participation of Intellectuals in the Advancement of Social Liberation in Africa. Journal of Pan African Studies, 10(3), 62-75.

Eyo, E. B., \& Etta, E. E. (2020). Ubuntu's philosophy and the challenge of Xenophobia: towards peace in Africa. International Journal of Humanities and Innovation (IJHI), 3(1), 39-43.

Eyo, E. B., \& Francis, D. A. I. (2017). A colloquy on violence and non-violence: towards a complementary conflict resolution. American journal of social issues and humanities, 7(2), 137-150.

Eyo, E. B., \& Ojong, F. E. (2008). Peace and Conflict Resolution as a Foundation for National Development. Sophia: An African Journal of Philosophy and Public Affairs, 11(1).

Gandhi, Mohandas K. (1957). Gandhi An Autobiography. The Story of my Experiments with Truth, Trans Maha Dev Desai, Boston: Becon Press.

Garrow, D. J. (1986). Bearing the Cross: Martin Luther King Jr. and the Southern Christian Leadership Conference, New. York: Morrow.

Gregg, R. B. (1960). The Power of Non-violence Ahmedabad: Navjivan Publishing House. 
Heitler, S. M. (1990). 'From Conflict to Resolution'. London: www.norton and Company.

Herman, A. L. (1998). Community, Violence and Peace: Aldo Leopold, M. K. Gandhi Martin Luther King Jr., and Gautama the Budda in the $21^{\text {st }}$ Century, Albany: State University of New York Press.

King Jr., Martin Luther (1986). "Pilgrimage to Non violence", in a Testament of Hope, The Essential Writings and Speeches of Martin Luther King Jr., James, M. Washington: (Ed) New York, Harper Collins Publishers.

King Jr., Martin Luther (1986). "The Social Organization of Non violence", in a Testament of Hope, The Essential Writings and Speeches of Martin Luther King Jr., James, M. Washington: (Ed) New York, Harper Collins Publishers.

King, Jr. Martin Luther Jr. (1986) "Non violence and Racial Justice", In a Testament of Hope, The Essential Writings and Speeches of Martin Luther King Jr. (Ed) James, M. Washington, New York, Harper Collins Publishers.

Michael, C. and Banks, M. (1998). Handbook of Conflict Resolution. London Pinter.

Nojeim, J. M. (2004). Life and Works of Gandhi and Martin King Jr. the Power of Nonviolent Resistance, Ohio, Beulahland Publications.

Oates, S. B. (1982). Let the Trumpet Sound: The Life of Martin Luther King Jr. New York, Harper and Ron.

Pontara, Guiliano (1978) “The Concept of Violence in Journal of Peace Research 15.2 